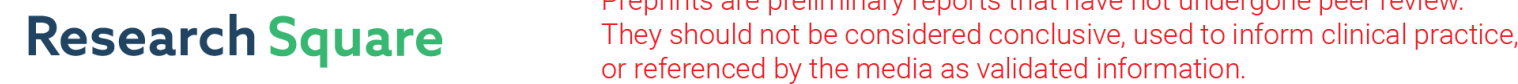

\section{Recent Trends in the Incidence of Clear Cell Adenocarcinoma and Survival Outcomes: A SEER Analysis}

Anil Shrestha

National Academy of Sciences

Niraj Maskey

Shanghai Tenth People's Hospital

Xiaohui Dong

Shanghai Jiaotong University First People's Hospital

Zongtai Zheng

Shanghai Tenth People's Hospital

Fuhan Yang

Shanghai Tenth People's Hospital

Ruiliang Wang

Shanghai Tenth People's Hospital

Wenchao Ma

Shanghai Tenth People's Hospital

Ji Liu

Shanghai Tenth People's Hospital

Cheng Li

Shanghai Tenth People's Hospital

Wentao Zhang

Shanghai Tenth People's Hospital

Shiyu Mao

Shanghai Tenth People's Hospital

Shenghua Liu

Shanghai Tenth People's Hospital

Xudong Yao ( $\sim$ yaoxudong1967@163.com )

Shanghai Tenth People's Hospital https://orcid.org/0000-0001-7234-3940

Yadong Guo

Tongji University

\section{Research article}

Keywords: clear cell adenocarcinoma, SEER database, incidence, survival

Posted Date: December 10th, 2020

DOI: https://doi.org/10.21203/rs.3.rs-121162/v1

License: @ (i) This work is licensed under a Creative Commons Attribution 4.0 International License. Read Full License 


\section{Abstract}

Objective. To investigate recent trends in the epidemiological and prognostic factors of clear cell adenocarcinoma (CCA) which is considered a relatively rare tumor with a glycogen-rich phenotype.

Methods. Patients with CCA from years 2000 to 2016 were identified from the Surveillance, Epidemiological, and End Results (SEER) database. Relevant population data were used to analyze the rates age-adjusted incidence, age-standardized 3-year and 5-year relative survivals, and overall survival (OS).

Results. Of the 104,206 CCA patients identified. The age-adjusted incidence of CCA increased 2.7-fold from the year 2000 (3.3/100,000) to 2016 $(8.8 / 100,000)$. This increase occurred across all ages, races, stages, and grades. Of all these subgroups, the increase was largest in the grade IV group. The age-standardized 3-year and 5-year relative survivals increased during this study period, rising by $9.1 \%$ and $9.5 \%$ from 2000 to 2011 , respectively. Among all the stages and grades, the relative survival increase was greatest in the grade IV group. According to multivariate analysis of all CCA patients, predictors of OS were: age, gender, year of diagnosis, marital status, race, grade, stage, and primary tumor site $(\mathrm{P}<0.001)$. The OS of all CCA patients during the period 2008 to 2016 was significantly higher than that from 2000 to 2007 (hazard ratio [HR], $0.87 ; 95 \% \mathrm{Cl}: 0.85-0.89 ; \mathrm{P}<0.001$ ).

Conclusions. The incidence of CCA and survival of these patients improved over time. In particular, the highest increases were reported for grade IV CCA, which may be due to an earlier diagnosis and improved treatment.

\section{Background}

Clear cell carcinoma (CCA) consists of a series of malignant tumors, likely caused by abnormal deposition of glycogen ${ }^{1}$. Glycogen is a branched-chain polysaccharide composed of glucose that is necessary to maintain homeostasis of normal cell metabolism, but can promote tumor growth, especially under adverse conditions ${ }^{2-4}$. Studies have shown that hypoxia within the centers of solid tumors leads to an increase in glycogen storage, allowing adaptation to low oxygen levels and lack of nutrients. The possible mechanism involves hypoxia-inducible factor 1a (HIF-1a)-mediated signaling pathways ${ }^{4,5}$. Therefore, the regulation of glycogen synthesis and degradation is crucial for cellular homeostasis. In recent years, more and more studies have emphasized that reprogramming of glycogen metabolism affects the occurrence and progression of malignant tumors; hence, it has become a recognized feature of tumor cells $^{6,7}$. Although a few drugs targeting glycogen metabolism are currently being tested as a component of comprehensive treatment for tumors, they have not yet been approved for clinical application ${ }^{8,9}$.

There is evidence that CCA shows striking similarities in the gene expression profiles of various organs ${ }^{10}$. In addition, histological staining of CCA tumors shows "clear cells" with a transparent and oval appearance that are rich in cytoplasmic glycogen. Since CAA has no obvious symptoms, its diagnosis is based on histopathological identification of these characteristics. Previous research also suggests a link between glycogen-rich tumors and tumor aggressiveness, and CCA of the kidney, ovary, and bladder have a poor prognosis and are resistant to treatment ${ }^{11-14}$. In addition, although studies have described the effect of CCA on the prognosis of some cancer patients, the epidemiology and survival of CCA patients in the general population have not been well described. Therefore, in this study, we attempted to perform the most complete analysis of the incidence, patient demographics, and prognostic factors of CCA using data from the Surveillance, Epidemiological, and End Results (SEER) program.

\section{Methods}

The SEER program is the definitive source of cancer incidence and survival data collected by the National Cancer Institute, covering approximately $34.6 \%$ of the US population. Our study used the SEER 18 database and identified all malignancies that were diagnosed as CCA between 1 January 2000 and 31 December 2016: kidney and renal pelvis (KRP); ovary; cervix and corpus uteri; lung and bronchus; urinary bladder; vagina; pancreas; breast; peritoneum, omentum, and mesentery (POM); prostate; and liver. The CD-0-3 histology code was used to identify CCA. This code corresponds to the following clinical/histological diagnoses: 8310/2, 8310/3, and 8313/3. The following information was collected from the database: primary tumor site; ICD-0-3 histology; age at diagnosis; gender; marital status; race; grade; tumor stage in 2000; and sites of metastasis at diagnosis (bone, brain, liver, and lung from years 2010 to 2016). Studies with a lack of survival data or fewer than 50 CCA solid tumors were excluded. The final cohort included 104,206 patients.

\section{Statistical analysis}

SEER`Stat software (version 8.3.6, National Cancer Institute Surveillance Research Program) was used to calculate the age-adjusted incidence and agestandardized relative survival. Incidence and relative survival were standardized to the 2000 United States general population.

All statistical analyses were performed using IBM SPSS v25.0 software (International Business Machines, Armonk, NY, USA). Differences in demographic and clinical characteristics of different primary tumor sites were determined using Pearson's chi-squared test. A multivariate Cox proportional hazards regression model was used to estimate the 3-year, 5-year, and overall survival (OS) for all patients, respectively. Two-tailed $P$ values $<0.05$ were considered statistically significant.

\section{Results}

\section{Annual incidence of CCA}

To assess the recent trends in CCA incidence, we identified all CCA cases from 2000 to 2016 in the SEER database. As shown in Figure 1 A, the incidence of age-adjusted CCA was 3.3 per 100,000 persons in 2000, and increased to 8.8 per 100,000 persons in 2016; for comparison, the annual age-adjusted incidence 
of all malignancies is also depicted.

In addition, we divided all CCA cases into different subgroups based on the age and race of the patient as well as grade and stage of the tumor. First, the agespecific incidence was calculated for three age groups: $<60$ years, $60-69$ years, and $>70$ years. As shown in Figure 1B, the incidence of CCA increased dramatically from 2000 to 2016 in patients aged $<60$ years, with nearly a 3-fold rise to 4.7 per 100,000 persons; among those aged 60-69 years or >70 years, there was a more modest increase of 2.5 -fold.

Among the tumor grade groups, the most dramatic rise in incidence was described in patients with grade IV CCA (from 0.1 per 100,000 persons in 2000 , to 0.7 per 100,000 persons in 2016; Figure 1C). Among the tumor stage groups, the incidence of localized CCA increased the most relative to regional or distant (from 2 per 100,000 persons in 2000 to 6.2 per 100,000 persons in 2016; Figure 1D). Among the ethnic groups, the incidence of CCA increased the most in Caucasians (from 2.1 per 100,000 persons in 2000 to 8.4 per 100,000 persons in 2016; Figure 1E).

Overall, according to the SEER 18 data, the incidence of CCA cases diagnosed increased statistically significantly from 2000 to 2016 (annual percent change (APC): $4.6,95 \%$ confidence interval $(\mathrm{Cl})[3.4,5.7], P<0.05)$.

\section{Patient characteristics}

To compare the demographic and clinical characteristics of CCA at the different primary tumor sites, we analyzed 104,206 CCA patients identified in the SEER database (Table 1). We found that the median age of these patients at diagnosis was 62 years (range: $53-71$ y), and the median $0 S$ was 46 months (range: 17-91 mo).

Comparing the different primary tumor sites, the lowest median age at diagnosis (56 y) was that of patients with ovarian CCA, and the highest (71 years) was for patients with bladder CCA. The median OS was best for CCA of the prostate (79 mo) and breast (72 mo), while the median OS was worst for CCA of the pancreas $(3 \mathrm{mo})$ and liver $(6.5 \mathrm{mo})$. All of these differences in OS were significant $(P<0.001$; Supplementary Figure $1 \mathrm{~A})$.

The primary tumor site in these patients was significantly associated with the age at diagnosis $(P<0.001 ;$ Table 1$)$. Patients aged $\geq 61$ years were more likely to develop primary CCA of the KRP, corpus and cervix uteri, lungs, bladder, pancreas, prostate, or liver; while patients aged 31-60 years were more likely to have CCA of the POM. Moreover, the tumor grade was significantly different between the various primary tumor sites $(P<0.001$; Table 1): patients with grade II tumors were more likely to have CCA of the KRP; while patients with grade III tumors were more likely to have CCA of the corpus and cervix uteri, lungs, breast, or prostate.

The tumor stage was significantly different between the various primary tumor sites $(P=0.001$; Table 1$)$ : localized CCA was more likely to be in the KRP, ovary, cervix uteri, breast, prostate, or liver; while distant CCA was more likely to be in the lungs or pancreas. In addition, we determined that the metastatic sites differed depending on the type of CCA. Patients with CCA of the KRP, cervix uteri, or vagina were most likely to have lung metastases; patients with CCA of the ovary, bladder, or pancreas were more prone to have liver metastases; and patients with CCA of the lung, breast, or prostate were tended to have bone metastases (Supplementary Figure 1B).

\section{Survival}

We identified the latest trends in the survival of all CCA cases from 2000 to 2011 in the SEER database, relative to the general population. As shown in Figure $2 \mathrm{~A}$, the age-standardized 3-year and 5-year relative survivals increased from 2000 to 2011 , rising by $9.1 \%$ and $9.5 \%$, respectively. Specifically, when we examined the CCA cases by grade (Figure 2B-C), we found that the age-standardized 3-year and 5-year relative survivals of patients with grade I CCA increased from $89.6 \%$ and $84.0 \%$ in 2000 to $98.1 \%$ and $96.0 \%$ in 2011 , respectively. Meanwhile, the age-standardized 3-year and 5-year relative survivals of patients with grade II CCA slightly improved from $85.4 \%$ and $79.7 \%$ in 2000 to $93.6 \%$ and $90.0 \%$ in 2011 , respectively.

Those with grade III-IV CCA showed an even greater improvement: the 3-year and 5-year relative survivals of grade III patients increased from $66.7 \%$ and $41.6 \%$ in 2000 to $79.8 \%$ and $63.5 \%$ in 2011 , respectively. The 3 -year and 5 -year relative survivals of the grade IV patients increased from $60.9 \%$ and $39.6 \%$ in 2000 to $73.8 \%$ and $51.1 \%$ in 2011 . When we examined the age-standardized 3 -year and 5 -year relative survivals by tumor stage, we found that the relative survival of patients with localized, regional, or distant tumors had improved slightly over time (Figure 2D-E).

The age-standardized 3-year and 5-year survivals of the CCA patients relative to the general population and according to the primary tumor site were analyzed (Figure $3 \mathrm{~A}$ ). The largest change in 3-year to 5-year survival was for CCA of the POM (46.8\% to $32.2 \%)$ or prostate (72.3\% to $59.2 \%)$, and the smallest change was for CCA of the pancreas $(11.4 \%$ to $8.3 \%)$ or KRP (85.6\% to $81.1 \%)$. We examined the known 3-year and 5 -year relative survivals of CCA of different primary tumor sites according to the tumor stage (Figure $3 \mathrm{~B}-\mathrm{C}$ ). The best 5 -year relative survival for regional and distant tumors was for patients with ovarian CCA.

We performed a multivariate analysis and calculated the hazard ratio for OS (Table 2). Age, gender, year of diagnosis, marital status, ethnicity, grade, stage, and primary tumor site were all significantly associated with OS. We found that women (HR, $0.85 ; 95 \% \mathrm{Cl}, 0.83-0.87)$ had a better $0 \mathrm{~S}$ than men, and patients with grade III (HR, 1.21; $95 \% \mathrm{Cl}, 1.16-1.26)$ or grade IV (HR, 1.68; 95\% Cl, 1.59-1.77) CCA had a worse OS than did those with grade I CCA. However, the OS was not statistically different between grade II and grade I CCA. After adjusting for other variables, regional CCA (HR, 1.91; 95\% Cl, 1.86-1.97) and distant CCA (HR, 8.29; 95\% Cl, 8.06-8.53) had a worse OS than did localized CCA. Compared with CCA of the KRP, patients with CCA of the liver had the worst OS (HR, 4.89; $95 \% \mathrm{Cl}, 3.71-6.44)$, those with CCA of the pancreas had the second worst OS (HR, 3.70; $95 \% \mathrm{Cl}, 2.99-4.59)$, and those with CCA of the ovary had the best OS (HR, 0.75; 95\% Cl, 0.71-0.79).

We analyzed the latest trends of the OS during 2000-2007 and 2008-2016. Compared with 2000-2007, the risk of death in CCA diagnosed in 2008-2016 was less by $13 \%(\mathrm{HR}, 0.87 ; 95 \% \mathrm{Cl}, 0.85-0.89)$. We calculated the 3-year and 5-year hazard ratios through multivariate analysis, and the patients with grade II 
CCA had better 3-year (HR, 0.84; 95\% Cl, 0.79-0.90) and 5-year (HR, 0.88; 95\% Cl, 0.83-0.93) survivals than did those patients with grade I CCA. All of the above comparisons are significant $(P<0.001)$.

\section{Discussion}

In this study, we used the SEER database to report the largest number of CCA cases for the first time, focusing on incidence, demographic characteristics, and prognostic factors. We found that the age-adjusted incidence of CCA increased from 3.3 per 100,000 persons in 2000 to 8.8 per 100,000 persons in 2016 , which is a 2.7 -fold increase. This increase may be due in part to factors such as increased early diagnosis of these tumors and insurance coverage ${ }^{15-17}$. The survival of CCA patients also increased significantly over time, reflecting that comprehensive treatment based on surgery has improved for CCA patients in recent years ${ }^{18-20}$.

Although the incidence increased across all ages, grades, stages, and races during this period, the incidence increased the most for grade IV CCA, then localized stage; and American Indians and Alaskan Natives among races. However, it is unclear whether these differences are due to underlying dietary habits, environmental factors, biological factors, or health care models. Furthermore, CCA is associated with variables such as older age, white, male, grade II and local stage. CCA also occurs most frequently in the kidneys and ovaries. Patients with kidney or ovarian CCA are more likely to have metastasis to the lungs and liver compared with other solid CCAs, respectively, a finding consistent with previous reports ${ }^{21,22}$.

In addition, we analyzed the relative survival of patients with all grades and stages of CCA and found that survival over time increased the most in patients with grade IV CCA. One possible explanation is that surgery-based comprehensive treatment models for high-grade CCA have improved in recent years ${ }^{23,24}$. The results of the multivariate survival analysis showed that age, gender, year of diagnosis, marital status, ethnicity, disease stage, grade, and primary tumor site are important predictors of the OS of CCA patients. We also found that the most useful predictor of prognosis in patients with CCA is probably the primary tumor site. Therefore, the results of our research above can be used as a practical guide for clinicians.

Previous studies have shown that CCA is formed by the abnormal accumulation of glycogen. The prognosis is poor for patients with CCA of the kidney, uterus, ovary, bladder, or breast $11,13,25,26$. The present research showed that compared with CCA of the kidney, CCA of the liver and pancreas has a relatively worse OS, while CCA of the ovary has a better prognosis.

The poor prognosis of CCA patients may be due to several biomolecular mechanisms. Glycogen metabolism has recently been recognized as an important pathway for metabolic reprogramming in cancer cells. Others have reported that tumorigenesis and progression inhibit hypoglycemic glycogen metabolism and thereby inhibit active oxygen levels and p53-dependent cell senescence ${ }^{14}$. Furthermore, tumor cells can mobilize glycogen to promote glycolysis and increase cancer cell proliferation, invasion, and metastasis through various signaling pathways such as p38a mitogen-activated protein kinase and mammalian target of rapamycin 27,28 .

Abnormal glycogen accumulation can serve as an important energy supply that compensate for nutritional deficiencies in the tumor microenvironment ${ }^{2}$. Therefore, targeting glucose metabolism is considered an important approach for cancer treatment ${ }^{4,8}$. However, there is currently no effective treatment for CCA. A deep understanding of cancer glycogen metabolism is needed to identify novel targeted treatments for these glycogen-rich cancers, to serve as options to surgery for comprehensive treatment.

There are some limitations to our research. First, this study was retrospective and had an inherent selection bias. Second, our study did not include factors such as the quality of surgery and systemic treatments, which may confound the results. Finally, the SEER database does not capture a number of possible prognostic indicators such as insurance status, eating habits, and environmental factors, which may also influence treatment decisions and survival outcomes.

\section{Conclusions}

In this large-scale study, we evaluated the incidence of CCA as well as the demographics and survival of CCA patients. Over time, the incidence of CCA and patient survival increased. In particular, the highest increases were reported for grade IV CCA compared with all subgroups, which may be due to increased diagnosis of the disease and improved treatment. Our research will help clinicians fully understand the natural history and progression of these glycogen-rich tumors as well as provide a theoretical basis for identifying novel targeted therapies.

\section{Abbreviations}

CCA, clear cell adenocarcinoma; HR, hazard ratio; KRP, kidney and renal pelvis; OS, overall survival; POM, peritoneum, omentum, and mesentery; SEER, Surveillance, Epidemiological, and End Results

\section{Declarations}

\section{Acknowledgments}

Our sincere gratitude to the NIH-SEER program for high-quality data for re- searchers. We also thank our colleagues for the assistance they accorded us.

\section{Author Contributions}


Conceptualization, Yadong Guo and xudong yao; Data curation, Anil Shrestha and xiaohui dong; Formal analysis, Niraj Maskey and xiaohui dong; Funding acquisition, xudong yao; Investigation, shiyu mao; Methodology, ruiliang wang; Project administration, Yadong Guo and xudong yao; Resources, wenchao ma; Software, Yadong Guo; Supervision, cheng li; Validation, ji liu and wentao zhang; Visualization, zongtai zheng and wentao zhang; Writing - review \& editing, Yadong Guo and xudong yao

\section{Funding}

This work was supported in part by grants from the Shanghai Science Committee Foundation (\#19411967700).

\section{Availability of data and materials}

The datasets generated and/or analyzed during the current study are available in the SEER repository (http://www.seer.cancer.gov).

Ethics approval and consent to participate

Our study was exempted from institutional review board approval because of using the de-identified data in the SEER database.

\section{Consent for publication}

Not applicable.

\section{Competing interests}

The authors declared that they had no competing interests.

\section{References}

1. MJ YZ P, AA D, et al. A GPX4-dependent cancer cell state underlies the clear-cell morphology and confers sensitivity to ferroptosis. Nature communications. 2019;10(1):1617. https://doi.org10.1038/s41467-019-09277-9.

2. Hsu PP, Sabatini DM. Cancer cell metabolism: Warburg and beyond. Cell. Sep 5 2008;134(5):703-7. https://doi.org10.1016/j.cell.2008.08.021.

3. M M, FI L, R L, et al. Absence of HIF1A Leads to Glycogen Accumulation and an Inflammatory Response That Enables Pancreatic Tumor Growth. Cancer research. 2019;79(22):5839-5848. https://doi.org10.1158/0008-5472.can-18-2994.

4. Hypoxia NCD, HIF1 and glucose metabolism in the solid tumour. Nature reviews Cancer. 2008;8(9):705 - 13. https://doi.org10.1038/nrc2468.

5. N P, D V, D C, et al. Hypoxia promotes glycogen accumulation through hypoxia inducible factor (HIF)-mediated induction of glycogen synthase 1. PloS one. 2010;5(3):e9644. https://doi.org10.1371/journal.pone.0009644.

6. WH K, PL B, CV D. Otto Warburg's contributions to current concepts of cancer metabolism. Nature reviews Cancer. 2011;11(5):325 - 37. https://doi.org10.1038/nrc3038.

7. CE Z, E F, AL H. Glycogen metabolism in cancer. Biochemical pharmacology. 2014;92(1):3-11. https://doi.org10.1016/j.bcp.2014.09.001.

8. Zois CE, Harris AL. Glycogen metabolism has a key role in the cancer microenvironment and provides new targets for cancer therapy. $J$ Mol Med (Berl). Feb 2016;94(2):137 - 54. https://doi.org10.1007/s00109-015-1377-9.

9. dB CVSCMFFPF, V L. Targeting Cancer Metabolism: Dietary and Pharmacologic Interventions. Cancer discovery. 2016;6(12):1315-1333. https://doi.org10.1158/2159-8290.cd-16-0615.

10. KK Z, T B, L G, et al. Gene expression profiles of serous, endometrioid, and clear cell subtypes of ovarian and endometrial cancer. Clinical cancer research: an official journal of the American Association for Cancer Research. 2005;11(18):6422-30. https://doi.org10.1158/1078-0432.ccr-05-0508.

11. JC C, AL CMLHZ W, ML B. Comparisons of outcome and prognostic features among histologic subtypes of renal cell carcinoma. The American journal of surgical pathology. 2003;27(5):612 - 24. https://doi.org10.1097/00000478-200305000-00005.

12. T S, T K, J K, et al. Clinical characteristics of clear cell carcinoma of the ovary: a distinct histologic type with poor prognosis and resistance to platinumbased chemotherapy. Cancer. 2000;88(11):2584-9. https://doi.org10.1002/1097-0142(20000601)88:11<2584::aid-cncr22>3.0.co;2-5.

13. Z Z, CJ K, P W, et al. Clear Cell Adenocarcinoma of the Urinary Bladder Is a Glycogen-Rich Tumor with Poorer Prognosis. Journal of clinical medicine. 2020;9(1). https://doi.org10.3390/jcm9010138.

14. E F, K B, MG C, et al. Glucose utilization via glycogen phosphorylase sustains proliferation and prevents premature senescence in cancer cells. Cell metabolism. 2012;16(6):751 - 64. https://doi.org10.1016/j.cmet.2012.10.017.

15. S A, A D, H C, V P, M Y. Do US thyroid cancer incidence rates increase with socioeconomic status among people with health insurance? An observational study using SEER population-based data. BMJ open. 2015;5(12):e009843. https://doi.org10.1136/bmjopen-2015-009843.

16. SA M, R S. Differential diagnosis of epithelioid and clear cell tumors in the liver. Seminars in diagnostic pathology. 2017;34(2):183-191. https://doi.org10.1053/j.semdp.2016.12.014.

17. B T-C DRC, KM L, et al. Clear cell and endometrioid carcinomas: are their differences attributable to distinct cells of origin? The Journal of pathology. 2017;243(1):26-36. https://doi.org10.1002/path.4934.

18. AZ D, LC L, S G, et al. Phase Ib/Il Clinical Trial of Pembrolizumab With Bevacizumab for Metastatic Renal Cell Carcinoma: BTCRC-GU14-003. Journal of clinical oncology: official journal of the American Society of Clinical Oncology. 2020:JC01902394. https://doi.org10.1200/jco.19.02394. 
19. A O, MM L, J K, et al. Adjuvant chemotherapy in patients with stage I endometrioid or clear cell ovarian cancer in the platinum era: a Surveillance, Epidemiology, and End Results Cohort Study, 2000-2013. Annals of oncology: official journal of the European Society for Medical Oncology. 2017;28(12):2985-2993. https://doi.org10.1093/annonc/mdx525.

20. A B, L A, B L, et al. Updated European Association of Urology Guidelines for Cytoreductive Nephrectomy in Patients with Synchronous Metastatic Clear-cell Renal Cell Carcinoma. European urology. 2018;74(6):805-809. https://doi.org10.1016/j.eururo.2018.08.008.

21. C QG Z, X G, et al. Incidence of bone metastasis and factors contributing to its development and prognosis in newly diagnosed renal cell carcinoma: a population-based study. Cancer management and research. 2018;10:2935-2944. https://doi.org10.2147/cmar.s170083.

22. C KD, Q Y T, et al. Sites of distant metastases and overall survival in ovarian cancer: A study of 1481 patients. Gynecologic oncology. 2018;150(3):460465. https://doi.org10.1016/j.ygyno.2018.06.022.

23. C F, D F, L DB, et al. Role of Stereotactic Body Radiation Therapy for the Management of Oligometastatic Renal Cell Carcinoma. The Journal of urology. 2019;201(1):70-75. https://doi.org10.1016/j.juro.2018.08.049.

24. U MSGSPPPW H, M L. Overall survival after stereotactic radiotherapy or surgical metastasectomy in oligometastatic renal cell carcinoma patients treated at two Swedish centres 2005-2014. Radiotherapy and oncology: journal of the European Society for Therapeutic Radiology and Oncology. 2018;127(3):501-506. https://doi.org10.1016/j.radonc.2018.04.028.

25. S AG. C, N S, L C. Clear cell carcinoma of the endometrium: a biological and clinical enigma. Anticancer research. 2010;30(4):1327-34.

26. Z Z, CJ K, H H, et al. Clinical Features, Survival and Prognostic Factors of Glycogen-Rich Clear Cell Carcinoma (GRCC) of the Breast in the U.S. Population. Journal of clinical medicine. 2019;8(2). https://doi.org10.3390/jcm8020246.

27. HA MC K, B A, et al. Fibroblasts Mobilize Tumor Cell Glycogen to Promote Proliferation and Metastasis. Cell metabolism. 2019;29(1):141-155.e9. https://doi.org10.1016/j.cmet.2018.08.007.

28. Koo J, Yue P, Gal AA, Khuri FR, Sun S-Y Maintaining Glycogen Synthase Kinase-3 Activity Is Critical for mTOR Kinase Inhibitors to Inhibit Cancer Cell Growth. Cancer Research. 2014;74(9):2555-2568. https://doi.org10.1158/0008-5472.can-13-2946.

\section{Tables}


Table 1

Descriptive demographic and clinical characteristics of patients with CCA according to primary tumor site.*

\begin{tabular}{|c|c|c|c|c|c|c|c|c|c|c|c|c|c|}
\hline Covariate & Total & KRP & Ovary & $\begin{array}{l}\text { Corpus } \\
\text { Uteri }\end{array}$ & Lung & $\begin{array}{l}\text { Cervix } \\
\text { Uteri }\end{array}$ & Bladder & Vagina & Pancreas & Breast & РОМ & Prostate & Liver \\
\hline$n$ & 104206 & 94882 & 4750 & 2557 & 914 & 496 & 133 & 112 & 92 & 89 & 68 & 59 & 54 \\
\hline \multicolumn{14}{|l|}{ Age (\%) } \\
\hline$\leq 30$ & $\begin{array}{l}926 \\
(0.9)\end{array}$ & $\begin{array}{l}843 \\
(0.9)\end{array}$ & $\begin{array}{l}26 \\
(0.5)\end{array}$ & $4(0.2)$ & $\begin{array}{l}1 \\
(0.1)\end{array}$ & $\begin{array}{l}46 \\
(9.3)\end{array}$ & $2(1.5)$ & $4(3.6)$ & $0(0.0)$ & $\begin{array}{l}0 \\
(0.0)\end{array}$ & $0(0.0)$ & $0(0.0)$ & $\begin{array}{l}0 \\
(0.0)\end{array}$ \\
\hline $31-60$ & $\begin{array}{l}46677 \\
(44.8)\end{array}$ & $\begin{array}{l}42269 \\
(44.5)\end{array}$ & $\begin{array}{l}3102 \\
(65.3)\end{array}$ & $\begin{array}{l}590 \\
(23.1)\end{array}$ & $\begin{array}{l}265 \\
(29.0)\end{array}$ & $\begin{array}{l}233 \\
(47.0)\end{array}$ & $\begin{array}{l}37 \\
(27.8)\end{array}$ & $\begin{array}{l}48 \\
(42.9)\end{array}$ & $25(27.2)$ & $\begin{array}{l}46 \\
(51.7)\end{array}$ & $\begin{array}{l}36 \\
(52.9)\end{array}$ & $\begin{array}{l}14 \\
(23.7)\end{array}$ & $\begin{array}{l}12 \\
(22.2\end{array}$ \\
\hline$\geq 61$ & $\begin{array}{l}56603 \\
(54.3)\end{array}$ & $\begin{array}{l}51770 \\
(54.6)\end{array}$ & $\begin{array}{l}1622 \\
(34.1)\end{array}$ & $\begin{array}{l}1963 \\
(76.8)\end{array}$ & $\begin{array}{l}648 \\
(70.9)\end{array}$ & $\begin{array}{l}217 \\
(43.8)\end{array}$ & $\begin{array}{l}94 \\
(70.7)\end{array}$ & $\begin{array}{l}60 \\
(53.6)\end{array}$ & $67(72.8)$ & $\begin{array}{l}43 \\
(48.3)\end{array}$ & $\begin{array}{l}32 \\
(47.1)\end{array}$ & $\begin{array}{l}45 \\
(76.3)\end{array}$ & $\begin{array}{l}42 \\
(77.8\end{array}$ \\
\hline \multicolumn{14}{|l|}{ Gender, n (\%) } \\
\hline Male & $\begin{array}{l}59587 \\
(57.2)\end{array}$ & $\begin{array}{l}58935 \\
(62.1)\end{array}$ & $0(0.0)$ & $0(0.0)$ & $\begin{array}{l}452 \\
(49.5)\end{array}$ & $0(0.0)$ & $\begin{array}{l}60 \\
(45.1)\end{array}$ & $0(0.0)$ & $49(53.3)$ & $\begin{array}{l}1 \\
(1.1)\end{array}$ & $0(0.0)$ & $\begin{array}{l}59 \\
(100.0)\end{array}$ & $\begin{array}{l}31 \\
(57.2\end{array}$ \\
\hline Female & $\begin{array}{l}44619 \\
(42.8)\end{array}$ & $\begin{array}{l}35947 \\
(37.9)\end{array}$ & $\begin{array}{l}4750 \\
(100.0)\end{array}$ & $\begin{array}{l}2557 \\
(100.0)\end{array}$ & $\begin{array}{l}462 \\
(50.5)\end{array}$ & $\begin{array}{l}496 \\
(100.0)\end{array}$ & $\begin{array}{l}73 \\
(54.9)\end{array}$ & $\begin{array}{l}112 \\
(100.0)\end{array}$ & $43(46.7)$ & $\begin{array}{l}88 \\
(98.9)\end{array}$ & $\begin{array}{l}68 \\
(100.0)\end{array}$ & $0(0.0)$ & $\begin{array}{l}23 \\
(42.6\end{array}$ \\
\hline \multicolumn{14}{|l|}{$\begin{array}{l}\text { Year of diagnosis, } \\
\text { n (\%) }\end{array}$} \\
\hline $2000-2007$ & $\begin{array}{l}34615 \\
(33.2)\end{array}$ & $\begin{array}{l}30439 \\
(32.1)\end{array}$ & $\begin{array}{l}2043 \\
(43.0)\end{array}$ & $\begin{array}{l}1017 \\
(39.8)\end{array}$ & $\begin{array}{l}543 \\
(59.4)\end{array}$ & $\begin{array}{l}228 \\
(46.0)\end{array}$ & $\begin{array}{l}59 \\
(44.4)\end{array}$ & $\begin{array}{l}57 \\
(50.9)\end{array}$ & $46(50.0)$ & $\begin{array}{l}57 \\
(50.9)\end{array}$ & $\begin{array}{l}37 \\
(54.4)\end{array}$ & $\begin{array}{l}50 \\
(84.7)\end{array}$ & $\begin{array}{l}39 \\
(72.2\end{array}$ \\
\hline 2008-2016 & $\begin{array}{l}69591 \\
(66.8)\end{array}$ & $\begin{array}{l}64443 \\
(67.9)\end{array}$ & $\begin{array}{l}2707 \\
(57.0)\end{array}$ & $\begin{array}{l}1540 \\
(60.2)\end{array}$ & $\begin{array}{l}371 \\
(40.6)\end{array}$ & $\begin{array}{l}268 \\
(54.0)\end{array}$ & $\begin{array}{l}74 \\
(55.6)\end{array}$ & $\begin{array}{l}55 \\
(49.1)\end{array}$ & $46(50.0)$ & $\begin{array}{l}32 \\
(49.1)\end{array}$ & $\begin{array}{l}31 \\
(45.6)\end{array}$ & $9(15.3)$ & $\begin{array}{l}15 \\
(27.8\end{array}$ \\
\hline \multicolumn{14}{|l|}{ Marital (\%) } \\
\hline Married & $\begin{array}{l}64284 \\
(61.7)\end{array}$ & $\begin{array}{l}59559 \\
(62.8)\end{array}$ & $\begin{array}{l}2557 \\
(53.8)\end{array}$ & $\begin{array}{l}1160 \\
(45.4)\end{array}$ & $\begin{array}{l}490 \\
(53.6)\end{array}$ & $\begin{array}{l}208 \\
(41.9)\end{array}$ & $\begin{array}{l}49 \\
(36.8)\end{array}$ & $\begin{array}{l}55 \\
(49.1)\end{array}$ & $55(59.8)$ & $\begin{array}{l}42 \\
(47.2)\end{array}$ & $\begin{array}{l}37 \\
(54.4)\end{array}$ & $\begin{array}{l}41 \\
(69.5)\end{array}$ & $\begin{array}{l}31 \\
(57.4\end{array}$ \\
\hline Widowed/Divorced & $\begin{array}{l}20294 \\
(19.5)\end{array}$ & $\begin{array}{l}17936 \\
(18.9)\end{array}$ & $\begin{array}{l}877 \\
(18.5)\end{array}$ & $\begin{array}{l}913 \\
(35.7)\end{array}$ & $\begin{array}{l}270 \\
(29.5)\end{array}$ & $\begin{array}{l}127 \\
(25.6)\end{array}$ & $\begin{array}{l}49 \\
(36.8)\end{array}$ & $\begin{array}{l}31 \\
(27.7)\end{array}$ & $25(27.2)$ & $\begin{array}{l}25 \\
(28.1)\end{array}$ & $\begin{array}{l}20 \\
(29.4)\end{array}$ & 7 (11.9) & $\begin{array}{l}14 \\
(25.9\end{array}$ \\
\hline Single & $\begin{array}{l}14864 \\
(14.3)\end{array}$ & $\begin{array}{l}13041 \\
(13.7)\end{array}$ & $\begin{array}{l}1126 \\
(23.7)\end{array}$ & $\begin{array}{l}348 \\
(13.6)\end{array}$ & $\begin{array}{l}126 \\
(13.8)\end{array}$ & $\begin{array}{l}136 \\
(27.4)\end{array}$ & $\begin{array}{l}19 \\
(14.3)\end{array}$ & $\begin{array}{l}18 \\
(16.1)\end{array}$ & $10(10.9)$ & $\begin{array}{l}17 \\
(19.1)\end{array}$ & $\begin{array}{l}8 \\
(11.8)\end{array}$ & $7(11.9)$ & $\begin{array}{l}8 \\
(14.8\end{array}$ \\
\hline Unknown & $\begin{array}{l}4764 \\
(4.6)\end{array}$ & $\begin{array}{l}4346 \\
(4.6)\end{array}$ & $\begin{array}{l}190 \\
(4.0)\end{array}$ & $\begin{array}{l}136 \\
(5.3)\end{array}$ & $\begin{array}{l}28 \\
(3.1)\end{array}$ & $\begin{array}{l}25 \\
(5.0)\end{array}$ & $\begin{array}{l}16 \\
(12.0)\end{array}$ & $8(7.1)$ & $2(2.2)$ & $\begin{array}{l}5 \\
(5.6)\end{array}$ & $3(4.4)$ & $4(6.8)$ & $\begin{array}{l}1 \\
(1.9)\end{array}$ \\
\hline \multicolumn{14}{|l|}{ Race, n(\%) } \\
\hline White & $\begin{array}{l}88231 \\
(84.7)\end{array}$ & $\begin{array}{l}80971 \\
(85.3)\end{array}$ & $\begin{array}{l}3709 \\
(78.1)\end{array}$ & $\begin{array}{l}1902 \\
(74.4)\end{array}$ & $\begin{array}{l}785 \\
(85.9)\end{array}$ & $\begin{array}{l}396 \\
(79.8)\end{array}$ & $\begin{array}{l}108 \\
(81.2)\end{array}$ & $\begin{array}{l}76 \\
(67.9)\end{array}$ & $81(88.0)$ & $\begin{array}{l}69 \\
(77.5)\end{array}$ & $\begin{array}{l}53 \\
(77.9)\end{array}$ & $\begin{array}{l}47 \\
(79.7)\end{array}$ & $\begin{array}{l}34 \\
(63.0\end{array}$ \\
\hline Black & $\begin{array}{l}7693 \\
(7.4)\end{array}$ & $\begin{array}{l}6869 \\
(7.2)\end{array}$ & $\begin{array}{l}194 \\
(4.1)\end{array}$ & $\begin{array}{l}410 \\
(16.0)\end{array}$ & $\begin{array}{l}88 \\
(9.6)\end{array}$ & $\begin{array}{l}51 \\
(10.3)\end{array}$ & $\begin{array}{l}21 \\
(15.8)\end{array}$ & $\begin{array}{l}21 \\
(18.8)\end{array}$ & $6(6.5)$ & $\begin{array}{l}9 \\
(10.1)\end{array}$ & $6(8.8)$ & $\begin{array}{l}10 \\
(16.9)\end{array}$ & $\begin{array}{l}8 \\
(14.8\end{array}$ \\
\hline Other & $\begin{array}{l}7633 \\
(7.3)\end{array}$ & $\begin{array}{l}6427 \\
(6.8)\end{array}$ & $\begin{array}{l}832 \\
(17.5)\end{array}$ & $\begin{array}{l}232 \\
(9.1)\end{array}$ & $\begin{array}{l}39 \\
(4.3)\end{array}$ & $\begin{array}{l}48 \\
(9.7)\end{array}$ & $4(3.0)$ & $\begin{array}{l}14 \\
(12.5)\end{array}$ & $5(5.4)$ & $\begin{array}{l}10 \\
(11.2)\end{array}$ & $\begin{array}{l}9 \\
(13.2)\end{array}$ & $1(1.7)$ & $\begin{array}{l}12 \\
(22.2\end{array}$ \\
\hline Unknown & $\begin{array}{l}649 \\
(0.6)\end{array}$ & $\begin{array}{l}615 \\
(0.6)\end{array}$ & $\begin{array}{l}15 \\
(0.3)\end{array}$ & $\begin{array}{l}13 \\
(0.5)\end{array}$ & $\begin{array}{l}2 \\
(0.2)\end{array}$ & $1(0.2)$ & $0(0.0)$ & $1(0.9)$ & $0(0.0)$ & $\begin{array}{l}1 \\
(1.1)\end{array}$ & $0(0.0)$ & $1(1.7)$ & $\begin{array}{l}0 \\
(0.0)\end{array}$ \\
\hline
\end{tabular}

\section{Grading, n (\%)}

\begin{tabular}{|c|c|c|c|c|c|c|c|c|c|c|c|c|c|}
\hline 1 & $\begin{array}{l}10823 \\
(10.4)\end{array}$ & $\begin{array}{l}10666 \\
(11.2)\end{array}$ & $\begin{array}{l}53 \\
(1.1)\end{array}$ & $\begin{array}{l}42 \\
(1.6)\end{array}$ & $\begin{array}{l}33 \\
(3.6)\end{array}$ & $\begin{array}{l}13 \\
(2.6)\end{array}$ & $0(0.0)$ & $1(0.9)$ & $4(4.3)$ & $\begin{array}{l}1 \\
(1.1)\end{array}$ & $1(1.5)$ & $2(3.4)$ & $\begin{array}{l}7 \\
(13.0\end{array}$ \\
\hline II & $\begin{array}{l}43452 \\
(41.7)\end{array}$ & $\begin{array}{l}42604 \\
(44.9)\end{array}$ & $\begin{array}{l}397 \\
(8.4)\end{array}$ & $\begin{array}{l}149 \\
(5.8)\end{array}$ & $\begin{array}{l}164 \\
(17.9)\end{array}$ & $\begin{array}{l}47 \\
(9.5)\end{array}$ & $7(5.3)$ & $8(7.1)$ & $14(15.2)$ & $\begin{array}{l}34 \\
(38.2)\end{array}$ & $2(2.9)$ & $\begin{array}{l}18 \\
(30.5)\end{array}$ & $\begin{array}{l}8 \\
(14.8\end{array}$ \\
\hline III & $\begin{array}{l}24787 \\
(23.8)\end{array}$ & $\begin{array}{l}21250 \\
(22.4)\end{array}$ & $\begin{array}{l}1613 \\
(34.0)\end{array}$ & $\begin{array}{l}1199 \\
(46.9)\end{array}$ & $\begin{array}{l}349 \\
(38.2)\end{array}$ & $\begin{array}{l}191 \\
(38.5)\end{array}$ & $\begin{array}{l}36 \\
(27.1)\end{array}$ & $\begin{array}{l}26 \\
(23.2)\end{array}$ & $19(20.7)$ & $\begin{array}{l}40 \\
(44.9)\end{array}$ & $\begin{array}{l}23 \\
(33.8)\end{array}$ & $\begin{array}{l}32 \\
(54.2)\end{array}$ & $\begin{array}{l}9 \\
(16.7\end{array}$ \\
\hline IV & $\begin{array}{l}6457 \\
(6.2)\end{array}$ & $\begin{array}{l}5019 \\
(5.3)\end{array}$ & $\begin{array}{l}806 \\
(17.0)\end{array}$ & $\begin{array}{l}456 \\
(17.8)\end{array}$ & $\begin{array}{l}31 \\
(3.4)\end{array}$ & $\begin{array}{l}79 \\
(15.9)\end{array}$ & $\begin{array}{l}40 \\
(30.1)\end{array}$ & $\begin{array}{l}13 \\
(11.6)\end{array}$ & $0(0.0)$ & $\begin{array}{l}2 \\
(2.2)\end{array}$ & $\begin{array}{l}9 \\
(13.2)\end{array}$ & $2(3.4)$ & $\begin{array}{l}0 \\
(0.0)\end{array}$ \\
\hline Unknown & $\begin{array}{l}18687 \\
(17.9)\end{array}$ & $\begin{array}{l}15343 \\
(16.2)\end{array}$ & $\begin{array}{l}1881 \\
(39.6)\end{array}$ & $\begin{array}{l}711 \\
(27.8)\end{array}$ & $\begin{array}{l}337 \\
(36.9)\end{array}$ & $\begin{array}{l}166 \\
(33.5)\end{array}$ & $\begin{array}{l}50 \\
(37.6)\end{array}$ & $\begin{array}{l}64 \\
(57.1)\end{array}$ & 55 (59.8) & $\begin{array}{l}12 \\
(13.5)\end{array}$ & $\begin{array}{l}33 \\
(48.5)\end{array}$ & $5(8.5)$ & $\begin{array}{l}30 \\
\text { (55.6 }\end{array}$ \\
\hline
\end{tabular}




\begin{tabular}{|c|c|c|c|c|c|c|c|c|c|c|c|c|c|}
\hline Covariate & Total & KRP & Ovary & $\begin{array}{l}\text { Corpus } \\
\text { Uteri }\end{array}$ & Lung & $\begin{array}{l}\text { Cervix } \\
\text { Uteri }\end{array}$ & Bladder & Vagina & Pancreas & Breast & POM & Prostate & Liver \\
\hline \multicolumn{14}{|c|}{ Stage, n (\%) } \\
\hline Local & $\begin{array}{l}71561 \\
(68.7)\end{array}$ & $\begin{array}{l}68150 \\
(71.8)\end{array}$ & $\begin{array}{l}1655 \\
(34.8)\end{array}$ & $\begin{array}{l}1075 \\
(42.0)\end{array}$ & $\begin{array}{l}273 \\
(29.9)\end{array}$ & $\begin{array}{l}210 \\
(42.3)\end{array}$ & $\begin{array}{l}75 \\
(56.4)\end{array}$ & $0(0.0)$ & $5(5.4)$ & $\begin{array}{l}59 \\
(66.3)\end{array}$ & $0(0.0)$ & $\begin{array}{l}36 \\
(61.0)\end{array}$ & $\begin{array}{l}23 \\
(42.6\end{array}$ \\
\hline Regional & $\begin{array}{l}19183 \\
(18.4)\end{array}$ & $\begin{array}{l}15925 \\
(16.8)\end{array}$ & $\begin{array}{l}1756 \\
(37.0)\end{array}$ & $\begin{array}{l}925 \\
(36.2)\end{array}$ & $\begin{array}{l}284 \\
(31.1)\end{array}$ & $\begin{array}{l}196 \\
(39.5)\end{array}$ & $\begin{array}{l}24 \\
(18.0)\end{array}$ & $0(0.0)$ & 30 (32.6) & $\begin{array}{l}23 \\
(25.8)\end{array}$ & $0(0.0)$ & $\begin{array}{l}10 \\
(16.9)\end{array}$ & $\begin{array}{l}10 \\
(18.5\end{array}$ \\
\hline Distant & $\begin{array}{l}12257 \\
(11.8)\end{array}$ & $\begin{array}{l}9990 \\
(10.5)\end{array}$ & $\begin{array}{l}1288 \\
(27.1)\end{array}$ & $\begin{array}{l}457 \\
(17.9)\end{array}$ & $\begin{array}{l}339 \\
(37.1)\end{array}$ & $\begin{array}{l}78 \\
(15.7)\end{array}$ & $\begin{array}{l}23 \\
(17.3)\end{array}$ & $0(0.0)$ & $53(57.6)$ & $\begin{array}{l}6 \\
(6.7)\end{array}$ & $0(0.0)$ & $\begin{array}{l}11 \\
(18.6)\end{array}$ & $\begin{array}{l}12 \\
(22.2\end{array}$ \\
\hline Unknown & $\begin{array}{l}1205 \\
(1.2)\end{array}$ & $\begin{array}{l}817 \\
(0.9)\end{array}$ & $\begin{array}{l}51 \\
(1.1)\end{array}$ & $\begin{array}{l}100 \\
(3.9)\end{array}$ & $\begin{array}{l}18 \\
(2.0)\end{array}$ & $\begin{array}{l}12 \\
(2.4)\end{array}$ & $\begin{array}{l}11 \\
(8.3)\end{array}$ & $\begin{array}{l}112 \\
(100.0)\end{array}$ & $4(4.3)$ & $\begin{array}{l}1 \\
(1.1)\end{array}$ & $\begin{array}{l}68 \\
(100.0)\end{array}$ & $2(3.4)$ & $\begin{array}{l}9 \\
(16.7\end{array}$ \\
\hline
\end{tabular}


Table 2

Multivariate survival analysis of patients with CCA receiving diagnoses from 2000 to 2016.

\begin{tabular}{|c|c|c|c|c|c|c|}
\hline \multirow[t]{2}{*}{ Covariate } & \multicolumn{2}{|l|}{ Overall Survival } & \multicolumn{2}{|l|}{ 3-Year Survival } & \multicolumn{2}{|l|}{ 5-Year Survival } \\
\hline & HR & $P$ value & HR & $P$ value & HR & $P$ value \\
\hline Age,y & & $<0.001$ & & $<0.001$ & & $<0.001$ \\
\hline$\leq 30$ & 1.00 (ref.) & & 1.00 (ref.) & & 1.00 (ref.) & \\
\hline $31-60$ & $2.76(2.16-3.52)$ & $<0.001$ & $1.66(1.23-2.23)$ & 0.001 & $1.94(1.48-2.55)$ & $<0.001$ \\
\hline$\geq 61$ & $5.63(4.41-7.19)$ & $<0.001$ & $2.34(1.74-3.15)$ & $<0.001$ & $2.86(2.18-3.75)$ & $<0.001$ \\
\hline \multicolumn{7}{|l|}{ Gender } \\
\hline Male & 1.00 (ref.) & & 1.00 (ref.) & & 1.00 (ref.) & \\
\hline Female & $0.85(0.83-0.87)$ & $<0.001$ & $0.94(0.91-0.97)$ & $<0.001$ & $0.90(0.88-0.93)$ & $<0.001$ \\
\hline \multicolumn{7}{|l|}{ Year of diagnosis } \\
\hline $2000-2007$ & 1.00 (ref.) & & 1.00 (ref.) & & 1.00 (ref.) & \\
\hline $2008-2016$ & $0.87(0.85-0.89)$ & $<0.001$ & $0.42(0.41-0.44)$ & $<0.001$ & $0.37(0.36-0.38)$ & $<0.001$ \\
\hline Marital & & $<0.001$ & & $<0.001$ & & $<0.001$ \\
\hline Married & 1.00 (ref.) & & 1.00 (ref.) & & 1.00 (ref.) & \\
\hline Widowed/Divorced & $1.44(1.40-1.48)$ & $<0.001$ & $1.28(1.23-1.32)$ & $<0.001$ & $1.28(1.25-1.33)$ & $<0.001$ \\
\hline Single & $1.26(1.22-1.30)$ & $<0.001$ & $1.15(1.10-1.20)$ & $<0.001$ & $1.18(1.14-1.23)$ & $<0.001$ \\
\hline Unknown & $0.99(0.93-1.05)$ & 0.619 & $0.97(0.90-1.05)$ & 0.483 & $0.93(0.87-0.99)$ & 0.032 \\
\hline Race & & $<0.001$ & & $<0.001$ & & $<0.001$ \\
\hline White & 1.00 (ref.) & & 1.00 (ref.) & & 1.00 (ref.) & \\
\hline Black & $1.20(1.15-1.25)$ & $<0.001$ & $1.20(1.14-1.26)$ & $<0.001$ & $1.18(1.13-1.24)$ & $<0.001$ \\
\hline Other & $0.91(0.87-0.95)$ & $<0.001$ & $1.00(0.94-1.06)$ & 0.909 & $0.96(0.92-1.02)$ & 0.163 \\
\hline Unknown & $0.26(0.18-0.36)$ & $<0.001$ & $0.27(0.18-0.42)$ & $<0.001$ & $0.31(0.22-0.46)$ & $<0.001$ \\
\hline Grading & & $<0.001$ & & $<0.001$ & & $<0.001$ \\
\hline I & 1.00 (ref.) & & 1.00 (ref.) & & 1.00 (ref.) & \\
\hline II & $0.96(0.92-1.00)$ & 0.059 & $0.84(0.79-0.90)$ & $<0.001$ & $0.88(0.83-0.93)$ & $<0.001$ \\
\hline III & $1.21(1.16-1.26)$ & $<0.001$ & $1.04(0.97-1.11)$ & 0.317 & $1.08(1.02-1.24)$ & 0.012 \\
\hline IV & $1.68(1.59-1.77)$ & $<0.001$ & $1.37(1.27-1.48)$ & $<0.001$ & $1.48(1.39-1.58)$ & $<0.001$ \\
\hline Unknown & $1.48(1.41-1.55)$ & $<0.001$ & $1.35(1.26-1.44)$ & $<0.001$ & $1.41(1.33-1.49)$ & $<0.001$ \\
\hline Stage & & $<0.001$ & & $<0.001$ & & $<0.001$ \\
\hline Local & 1.00 (ref.) & & 1.00 (ref.) & & 1.00 (ref.) & \\
\hline Regional & $1.91(1.86-1.97)$ & $<0.001$ & $1.64(1.57-1.71)$ & $<0.001$ & $1.66(1.60-1.72)$ & $<0.001$ \\
\hline Distant & $8.29(8.06-8.53)$ & $<0.001$ & $3.92(3.78-4.07)$ & $<0.001$ & $4.49(4.34-4.64)$ & $<0.001$ \\
\hline Unknown & $2.90(2.66-3.16)$ & $<0.001$ & $2.56(2.30-2.83)$ & $<0.001$ & $2.33(2.12-2.56)$ & $<0.001$ \\
\hline Site & & $<0.001$ & & & & \\
\hline KRP & 1.00 (ref.) & & 1.00 (ref.) & & 1.00 (ref.) & \\
\hline Ovary & $0.75(0.71-0.79)$ & $<0.001$ & $0.87(0.82-0.93)$ & $<0.001$ & $0.90(0.85-0.96)$ & 0.001 \\
\hline Corpus Uteri & $1.16(1.09-1.23)$ & $<0.001$ & $1.10(1.02-1.18)$ & 0.01 & $1.22(1.25-1.31)$ & $<0.001$ \\
\hline Lung & $2.10(1.95-2.26)$ & $<0.001$ & $1.55(1.42-1.70)$ & $<0.001$ & $1.78(1.64-1.93)$ & $<0.001$ \\
\hline Cervix Uteri & $1.29(1.13-1.48)$ & $<0.001$ & $1.10(0.94-1.28)$ & 0.229 & $1.46(1.26-1.68)$ & $<0.001$ \\
\hline Bladder & $1.64(1.32-2.03)$ & $<0.001$ & $1.34(1.06-1.69)$ & 0.016 & $1.69(1.35-2.12)$ & $<0.001$ \\
\hline Vagina & $1.04(0.80-1.35)$ & 0.762 & $0.83(0.61-1.12)$ & 0.227 & $0.96(0.73-1.26)$ & 0.762 \\
\hline Pancreas & $3.70(2.99-4.59)$ & $<0.001$ & $2.77(2.22-3.45)$ & $<0.001$ & $3.56(2.86-4.43)$ & $<0.001$ \\
\hline
\end{tabular}




\begin{tabular}{|lllllll|}
\hline Covariate & Overall Survival & & 3-Year Survival & \multicolumn{3}{l|}{ 5-Year Survival } \\
\cline { 2 - 7 } & HR & P value & HR & P value & HR & P value \\
\hline Breast & $1.00(0.71-2.41)$ & 0.992 & $1.14(0.65-2.01)$ & 0.65 & $1.16(0.76-1.78)$ & 0.493 \\
POM & $1.77(1.33-2.36)$ & $<0.001$ & $0.96(0.68-1.35)$ & 0.804 & $0.90(0.67-1.22)$ & 0.502 \\
\hline Prostate & $0.94(0.68-1.30)$ & 0.728 & $0.89(0.55-1.43)$ & 0.624 & $0.72(0.48-1.07)$ & 0.102 \\
\hline Liver & $4.89(3.71-6.44)$ & $<0.001$ & $2.12(158-2.86)$ & $<0.001$ & $2.46(1.84-3.28)$ & $<0.001$ \\
\hline
\end{tabular}

\section{Figures}

\section{Figure1}
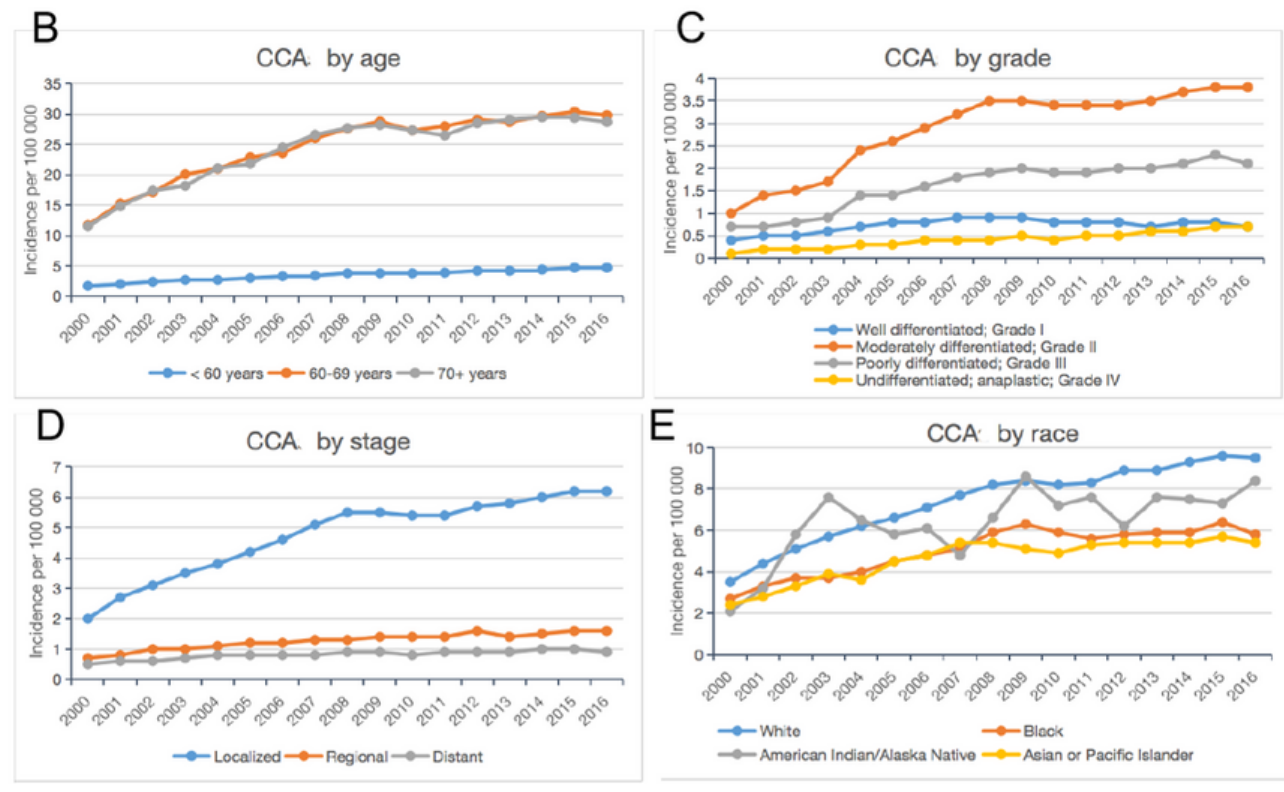

\section{Figure 1}

Incidence trends of CCA from 2000 to 2016. Annual age-adjusted incidence of all CCA cases and all malignant neoplasms (A). Annual age-adjusted incidence of CCA by age group (B), stage (C), grade (D), and ethnicity (E). 
Figure1

A

All CCA and malignant neoplasms
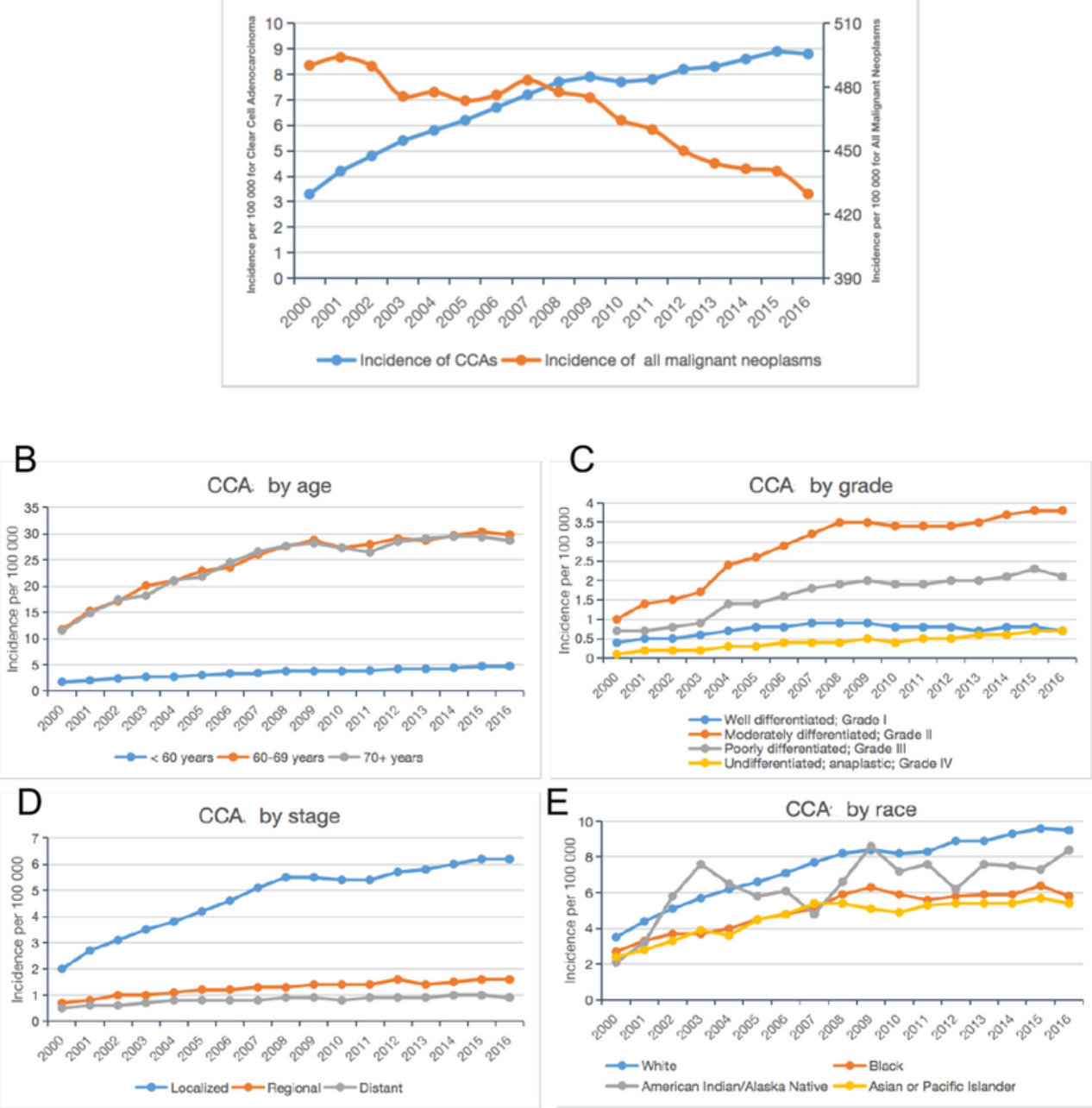

E

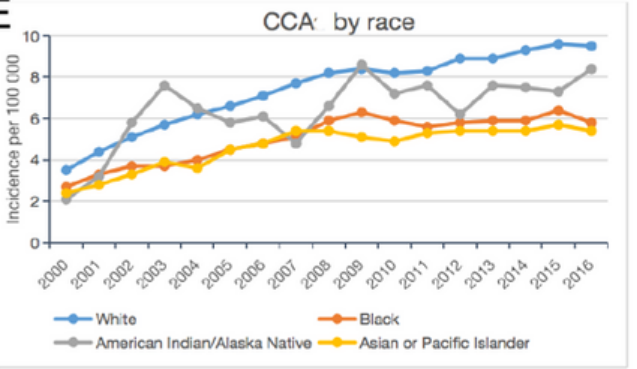

\section{Figure 1}

Incidence trends of CCA from 2000 to 2016. Annual age-adjusted incidence of all CCA cases and all malignant neoplasms (A). Annual age-adjusted incidence of CCA by age group (B), stage (C), grade (D), and ethnicity (E). 
Figure 2
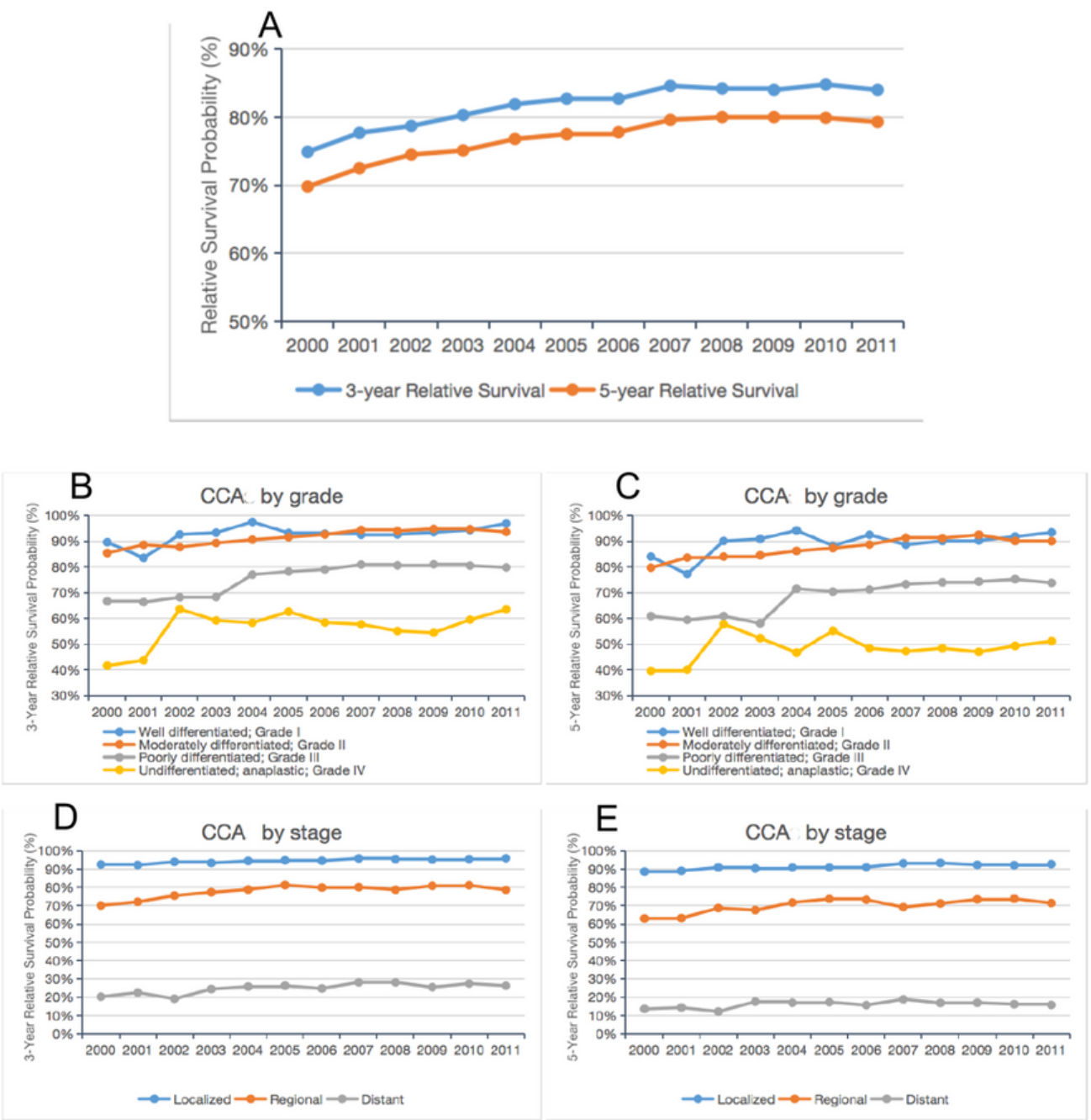

\section{Figure 2}

Trends in the 3-year and 5-year relative survival probabilities of CCA patients from 2000 to 2011. Trends in the 3-year and 5-year relative survival probabilities of all CCA patients (A). Trends in the 3-year and 5-year relative survival probabilities of CCA patients by grade (B, C) and stage (D, E). 
Figure 2
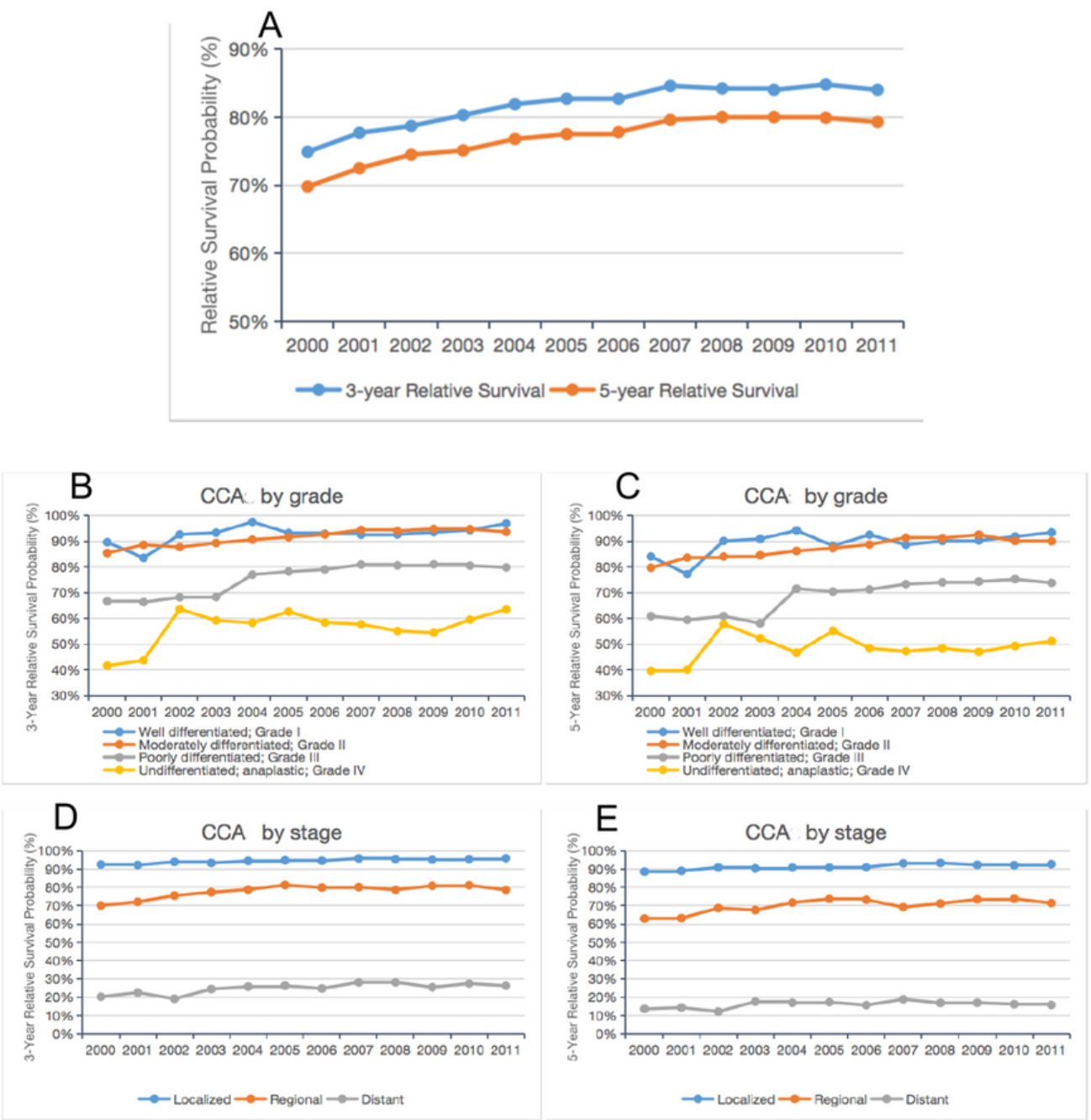

\section{Figure 2}

Trends in the 3-year and 5-year relative survival probabilities of CCA patients from 2000 to 2011. Trends in the 3-year and 5-year relative survival probabilities of all CCA patients (A). Trends in the 3-year and 5-year relative survival probabilities of CCA patients by grade (B, C) and stage (D, E). 


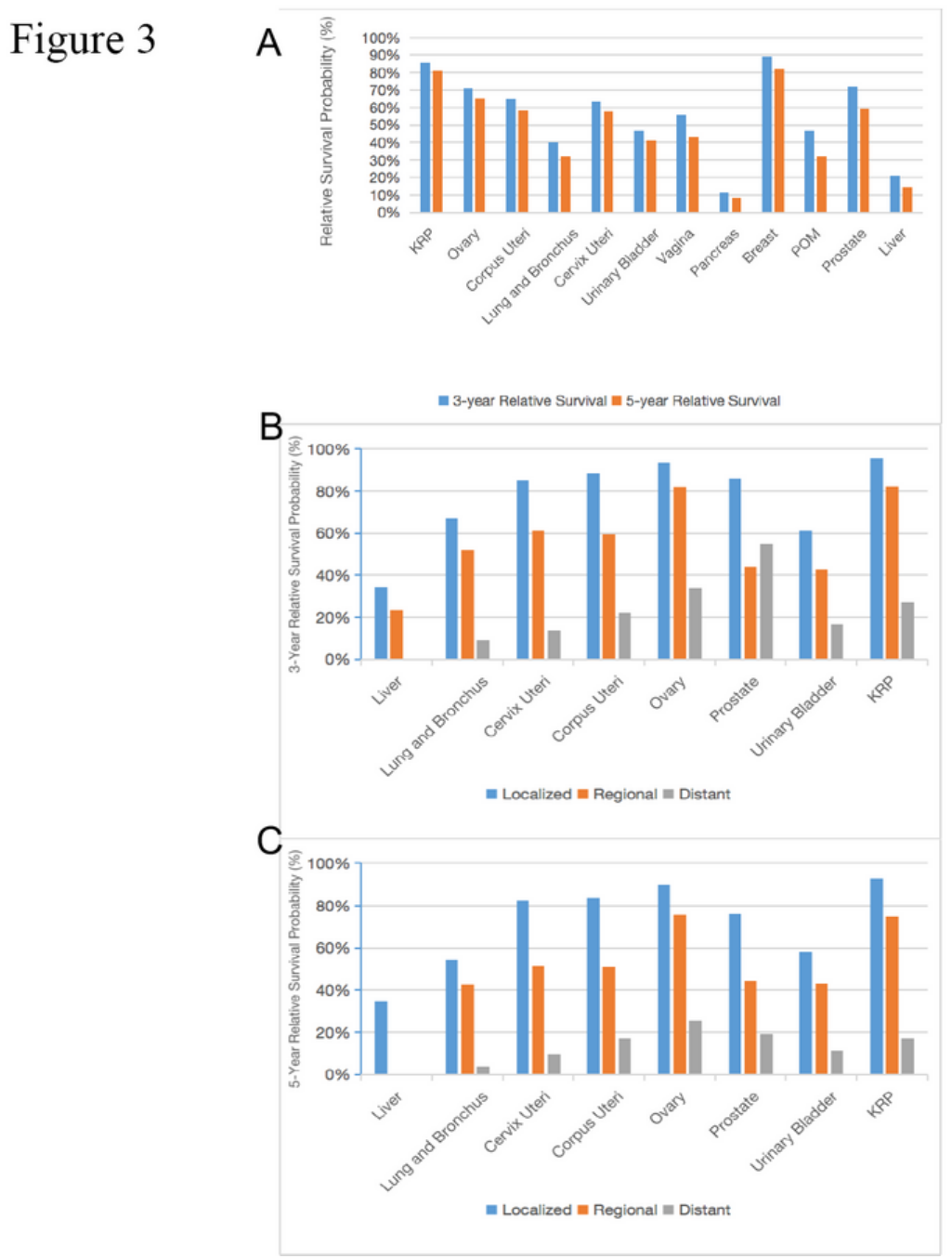

Figure 3

Trends in the 3-year and 5-year relative survival probabilities according to the primary tumor site. Trends in the 3-year and 5-year relative survival probabilities of patients with CCA at various primary tumor sites (A). Trends in the 3-year and 5-year relative survival probabilities by stage (B, C). 


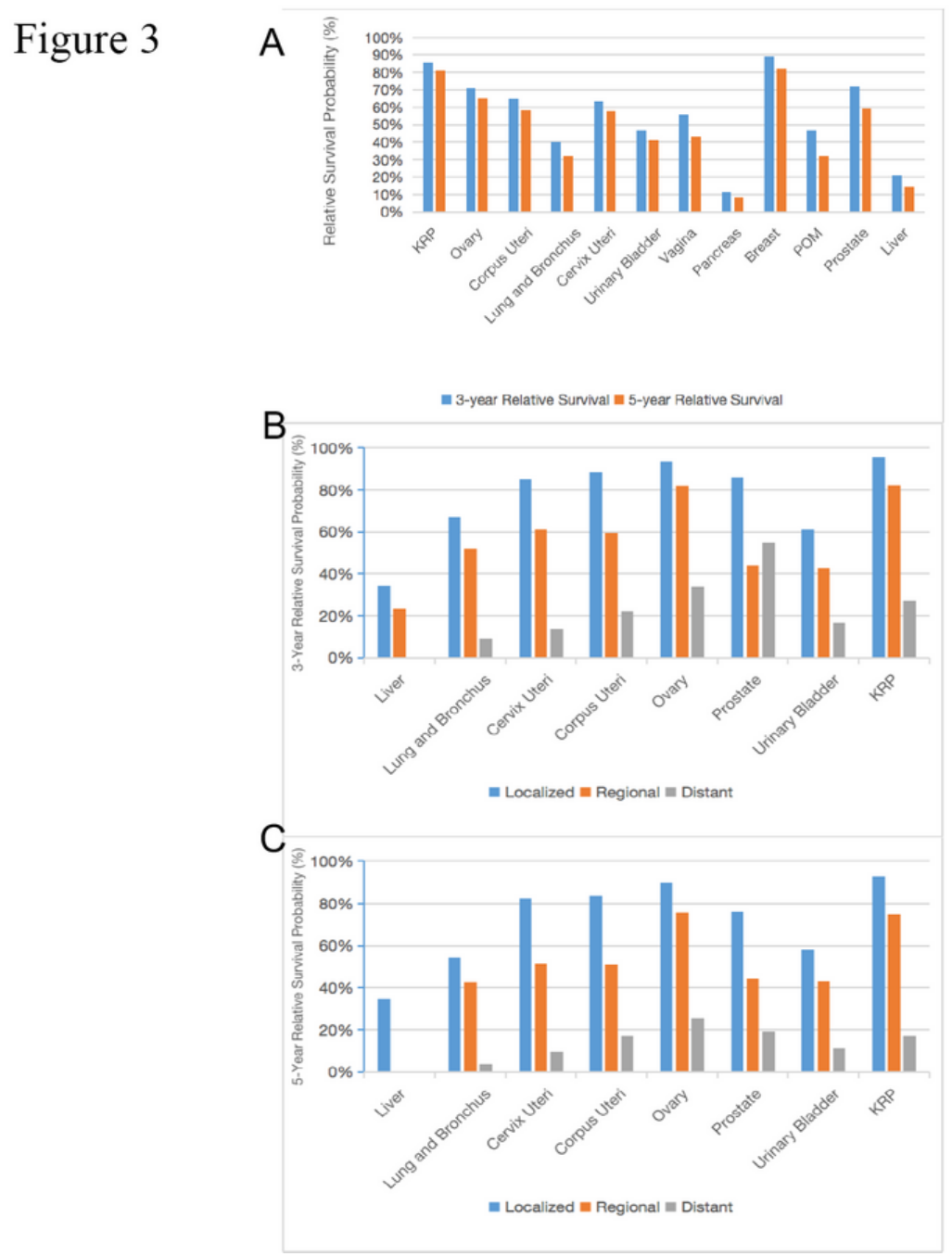

\section{Figure 3}

Trends in the 3-year and 5-year relative survival probabilities according to the primary tumor site. Trends in the 3-year and 5-year relative survival probabilities of patients with CCA at various primary tumor sites (A). Trends in the 3-year and 5-year relative survival probabilities by stage (B, C).

\section{Supplementary Files}

This is a list of supplementary files associated with this preprint. Click to download.

- SupplementaryFigure.docx

- SupplementaryFigure.docx 